\title{
Crystallographic texture of Late Triassic gastropod nacre: evidence of long-term stability of the mechanism controlling its formation
}

\author{
JIŘí FRÝDA, KLAUS BANDEL \& BARBORA FRÝDOVÁ
}

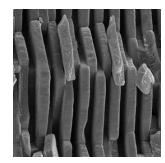

\begin{abstract}
An analysis of the crystallographic texture of nacre (mother-of-pearl) in the Late Triassic gastropod Wortheniella coralliophila is presented. The primary aim of this study was to test the time stability of the crystallographic texture pattern of gastropod nacre over an extremely long time span. Our results show that the crystallographic axes of individual aragonite platelets in the Late Triassic Wortheniella coralliophila have an identical arrangement to those in living vetigastropods. The same microstructure as well as the crystallographic texture of nacre in Recent and Late Triassic gastropods implies the same biological mechanisms for its formation. Our study suggests that the proteins controlling the shape and orientation of individual nacreous platelets in living gastropods have not changed since the Late Triassic. The molecular mechanisms driving the origin and the development of gastropod nacre are thus extremely old and have remained unchanged for at least 220 million years. $•$ Key words: Gastropoda, nacre, crystallographic texture, time stability.
\end{abstract}

FRÝDA, J., BANDEL, K. \& FRÝDOVÁ, B. 2009. Crystallographic texture of Late Triassic gastropod nacre: evidence of long-term stability of the mechanism controlling its formation. Bulletin of Geosciences 84(4), 745-754 (4 figures, 1 table). Czech Geological Survey, Prague. ISSN 1214-1119. Manuscript received October 30, 2009; accepted in revised form December 9, 2009; published online December 18, 2009; issued December 31, 2009.

Jiři Frýda, Czech Geological Survey, P.O.B. 85, 11821 Prague 1, and Faculty of Environmental Sciences, Czech University of Life Sciences Prague, Kamýcká 129, Praha 6 - Suchdol, 165 21, Czech Republic; bellerophon@seznam.cz• Klaus Bandel, Universität Hamburg, Geologisch Paläontologisches Institut und Museum, Bundesstrasse 55, 20146 Hamburg, Germany; klausbandel@yahoo.com • Barbora Frýdová, VÚRV v.v.i., Research Institute, Drnovská 507, 16106 Prague - Ruzyně, Czech Republic

Several months ago, a team of Japanese scientists (Suzuki et al. 2009) reported the discovery of two novel proteins, named Pif80 and Pif97, which seem to be the key players in controlling the crystal structure of nacre in pearl-forming oysters. The mechanisms determining the shape and orientation of individual calcium carbonate crystals in molluscan shells are very complex and poorly understood even though they had been intensively studied during past decades (see Checa \& Rodrigues-Navarro 2005, Marin et al. 2008, and Suzuki et al. 2009, for details and references). The application of electron microscopy has enabled us to analyze the detailed distribution of aragonite and calcite in individual shell layers as well as their microstructural patterns. This research has revealed the extremely high microstructural disparity of molluscan shells (e.g., Carter 1990). However, this work is far from complete because the shell microstructure of many, highly diversified groups of molluscs has not yet been studied. For example, the shell microstructure of living members of the Neritimorpha (a highly diversified order of marine, freshwater and terrestrial gastropods) has only been characterized in a few spe- cies (Sasaki 2001). Similarly, data on the shell microstructure for the vast majority of 605 family rank taxa of gastropods (Bouchet et al. 2005) are still not available.

The research aimed at understanding the mechanisms of shell formation on a molecular basis started at the same time as studies of microstructural patterns of molluscan shells. It has been shown that molluscan shells represent a complex composite material containing not only calcium carbonate crystals but also various organic macromolecules. These macromolecules form a matrix - a framework in which mineral crystals grow. The major components of the organic matrix are polysaccharide b-chitin, a relatively hydrophobic silk protein, and a complex assemblage of hydrophilic proteins, many of which are unusually rich in aspartic acid (see Addadi et al. 2006, and Marin et al. 2008, for details and references). Biochemical studies of molluscan shell formation have produced evidence that macromolecules present in the shell control the polymorphism of calcium carbonate. Aragonite is a phase which dominates in molluscan shells, but both aragonite and calcite shell layers are present in many species. Falini et al. 


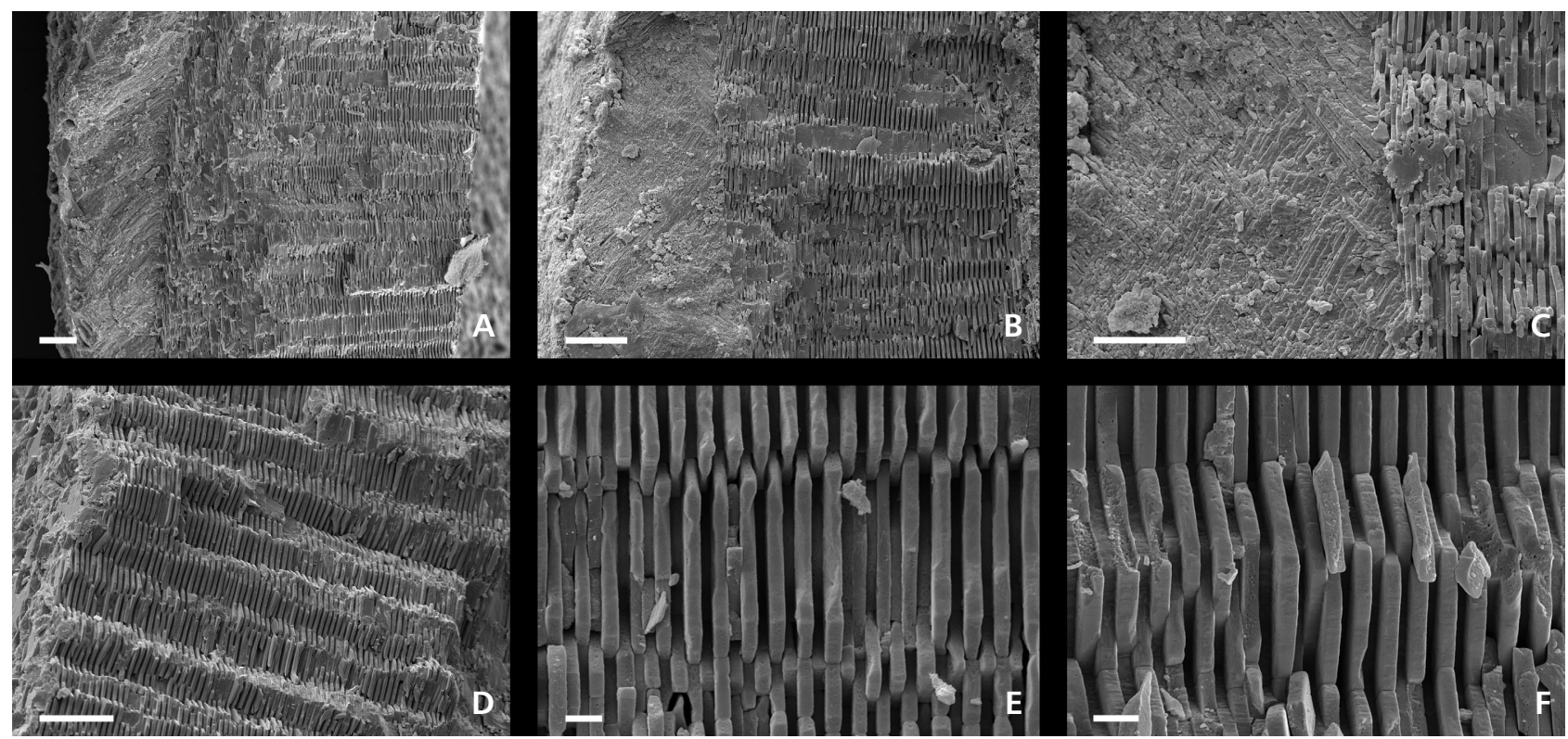

Figure 1. Secondary electron images of shell fragments of the Late Triassic Wortheniella coralliophila Kittl, 1891, from the St. Cassian Formation. - A, B - overall views of broken shell showing its outer layer (left) composed of spherulite sectors and inner nacreous layer (right). $\bullet$ - detailed view of the boundary between spherulitic and nacreous layers. $\bullet \mathrm{D}-$ view of the inner layer showing the columnar arrangement of nacreous platelets. $\bullet$ E, F - detailed views of nacreous platelets. Localities: A, D and F - Campo, B, C and E - Misurina; both localities near the Cortina d'Ampezzo, Dolomites. Scale bars: A, B, D $-20 \mu \mathrm{m}$; C $-10 \mu \mathrm{m} ; \mathrm{E}, \mathrm{F}-2 \mu \mathrm{m}$.

(1996) showed that macromolecules extracted from the aragonite shell layer induced the growth of aragonite in vitro on a substrate of polysaccharide b-chitin and hydrophobic silk protein. Under the same conditions, the macromolecules extracted from the calcite shell layer induce the growth of calcite. Falini et al. (1996) suggested that these macromolecules are responsible for the precipitation of either aragonite or calcite also in vivo. This discovery began a period of intensive research to identify the particular macromolecules responsible for the biomineralization processes as well as to understand shell formation at the molecular level (see details in Marin \& Luquet 2004, Suzuki et al. 2009). These studies have revealed many important insights into the mechanisms of shell formation on the molecular level (see Marin et al. 2008 for summary). On the other hand, during the last decade, studies of the inorganic part of molluscan shells (biocrystals of aragonite or calcite) have become less frequent and have been focused mainly on analyses of the mechanical properties of particular shell layers (e.g., Bertoldi et al. 2008) or on models explaining the growth of biocrystals (e.g., Checa et al. 2006; Checa \& Rodrigues-Navarro 2001, 2005). However, studies of the shell microstructure can also provide important data for understanding molluscan phylogeny. It has been known since the beginning of the last century (Bøggild 1930) that particular types of shell microstructures are limited to certain phylogenetic lineages of living mollusks (e.g., nacre is lacking in all living gastropods except for some members of the Vetigastropoda). In addition, it has been shown that microstructural data may characterize "high-level" taxa and therefore are an important source of information for phylogenetic analyses of major molluscan groups (e.g., MacClintock 1968, Bandel 1979, Carter 1990, Ponder \& Lindberg 1997).

The Patellogastropoda may represent one of the few good examples of the usage of microstructure data for family rank taxonomy. Shells of these exclusively marine gastropods are very simple (limpet), but their internal shell structure is the most complex among all living gastropods. In contrast to their shell microstructure, morphological features of their shells thus provide only a limited phylogenetic signal. The patellogastropod shells are formed of several different aragonite and/or calcite shell layers. Many non-redundant characteristics diagnostic of particular patellogastropod clades may be inferred from such complex shell structures (MacClintock 1968, Bandel \& Geldmacher 1996, Fuchigami \& Sasaki 2005). Also, the oldest known member of the Patellogastropoda was identified only by its shell microstructure (Hedegaard et al. 1997). However, the usage of shell microstructure data for the determination of phylogenetic position of fossil molluscs is exceptional rather than common.

Molluscan shells are formed by thousands of minute crystals of aragonite and/or calcite arranged in different shell layers. Therefore, this very complex composite material can provide three basic types of information on its inorganic component (i.e., information on the shell microstructure, phase composition, and crystallographic 


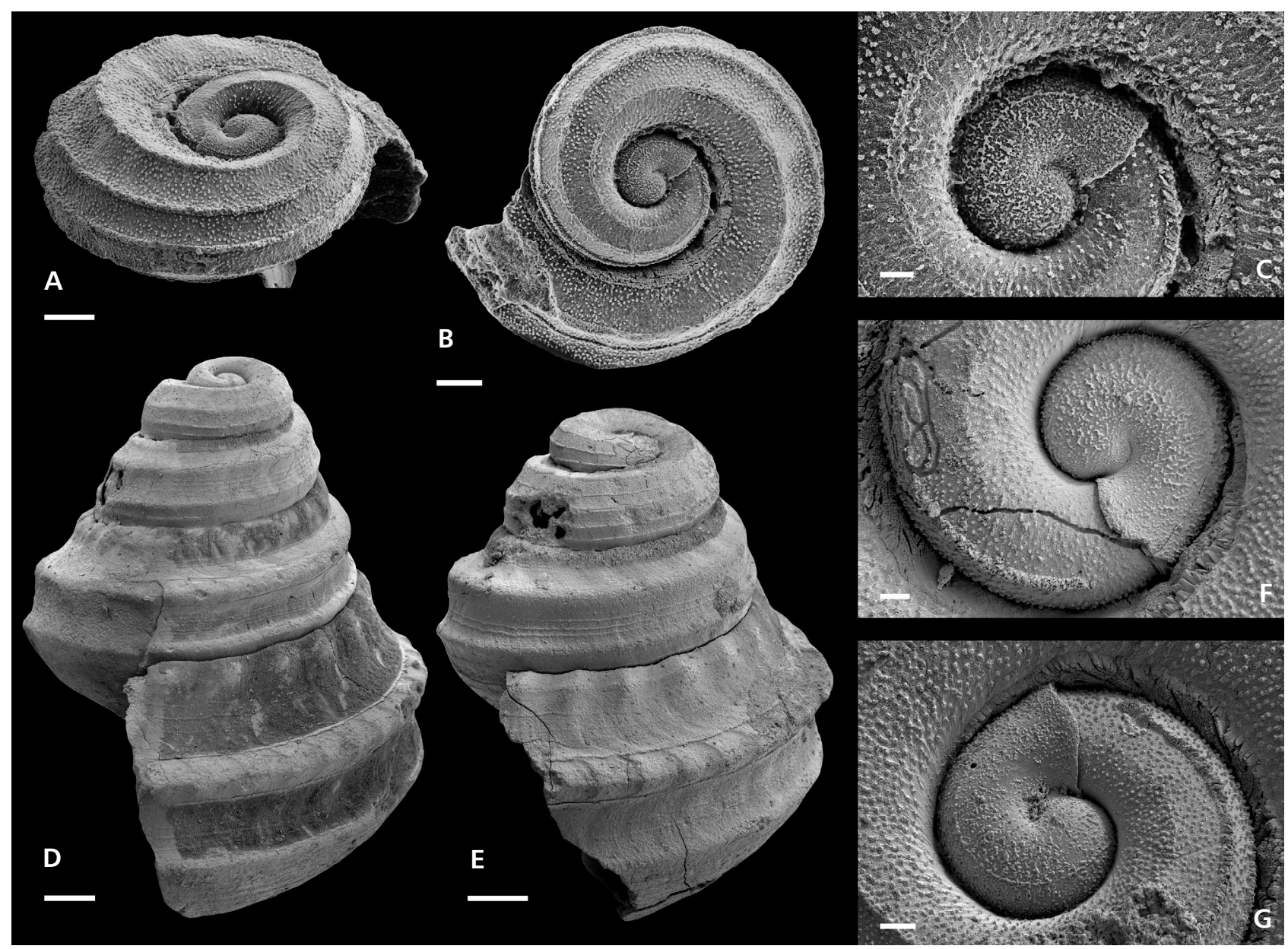

Figure 2. Late Triassic Wortheniella coralliophila Kittl, 1891, and Wortheniella subpunctata (Laube, 1868) from the St. Cassian Formation. - A, B - oblique and apical views of juvenile teleoconch of Wortheniella coralliophila showing almost planispirally coiled first whorl and protoconch in depression. $\bullet \mathrm{C}$ - detailed view of protoconch in specimen figured in A and $\mathrm{B} . \bullet \mathrm{D}, \mathrm{E}-$ oblique lateral views of teleoconch in Wortheniella coralliophila showing its selenizone and flat apex. $\bullet \mathrm{F}$ - detail of the protoconch of specimen figured in $\mathrm{E}$. $\bullet \mathrm{F}$ - detail of protoconch of Wortheniella subpunctata (Laube, 1868). Localities: A, B, C, D and G - Misurina; E and F - Alpe di Specie; both localities near the Cortina d'Ampezzo, Dolomites. Scale bars: A, B $-100 \mu \mathrm{m} ; \mathrm{C}-30 \mu \mathrm{m} ; \mathrm{D}, \mathrm{E}-200 \mu \mathrm{m} ; \mathrm{F}, \mathrm{G}-20 \mu \mathrm{m}$.

texture). The microstructure characterizing the shape of biocrystals has been the most studied property of molluscan shells. Data on phase composition (i.e., on the type of mineral forming a particular shell layer) are very rare and for many major molluscan groups are missing (they have been frequently inferred indirectly from shell microstructural type of a particular shell layer). The crystallographic texture, describing the arrangement of crystal axes of individual biocrystals, also provides an important set of characters for definition of the nature of individual shell layers. It has to be noted that shell layers having the same microstructure may have different crystallographic textures and vice versa. Thus, an analysis of crystallographic texture and microstructure of molluscan shells provides non-redundant characteristics. However, in contract to the microstructures, there are almost no data on crystallographic textures of molluscan shells. So far, only a few shell layers in several tens of the many tens of thousands of living molluscan species have been studied (Hedegaard 1997, Hedegaard \& Wenk 1998, Chateigner et al. 2000). Data on the crystallographic texture of shells in extinct molluscan species practically do not exist.

In this paper, we present results of crystallographic texture analysis of nacre in the fossil gastropod, Wortheniella coralliophila Kittl, 1891, from the Late Triassic St. Cassian Formation. The present study is part of an on-going project focused on the evolution of nacre in different groups of living and extinct molluscs. The main goal of this short paper is to test whether the crystallographic texture of gastropod nacre has changed during the past $200 \mathrm{Ma}$. The crystallographic texture is under biological control as is the shell microstructure, and therefore its study can reveal how stable are the biological mechanisms controlling biomineralization processes during an extremely long time interval. 


\section{Material and methods}

Gastropod nacre (mother-of-pearl) was selected for the test of time stability of the crystallographic texture of molluscan nacre over an extremely long period of time for several reasons. First, nacre is considered to be one of simplest and also one of the oldest of all molluscan microstructures. In addition, gastropod nacre occurs only in one of several major gastropod clades which makes phylogenetic as well as taxonomic placement of studied gastropods easier (see Discussion). Nacre is formed of regularly arranged aragonite platelets (Fig. 1). In fossil molluscs, aragonite in the shell usually became unstable and transformed into the more stable calcite during diagenesis. Thus, the presence of an aragonitic shell layer is a good indicator of the preservation of the original microstructural as well as textural features in fossil shells. Findings of aragonitic shells in fossil molluscs are generally less frequent with increasing geological age. Aragonitic fossils are relatively common in the Cenozoic, rare in Mesozoic, and extremely rare in Late $\mathrm{Pa}-$ leozoic strata. No aragonitic molluscan shells have been found in Lower Paleozoic beds.

For our test, we decided to use a very old gastropod taxon with known phylogenetic position. For this reason the Late Triassic Wortheniella coralliophila Kittl, 1891, from the St. Cassian Formation was selected (Fig. 2). The phylogenetic position of this species was recently revised (Bandel 2009). Development of a typical protoconch (Fig. 2C, F) as well as presence of nacre (Fig. 1) in the Late Triassic Wortheniella coralliophila Kittl, 1891, places it in the archaeogastropod clade (Bandel 1982, Schwardt 1992, Sasaki 1998; see Discussion). The genus Wortheniella Schwardt, 1992, is present as several common species in the Late Triassic St. Cassian Formation, from which the studied specimens of Wortheniella coralliophila originated. The St. Cassian Formation has provided the most important and most diversified Triassic gastropod fauna known to date (list of papers dealing with the St. Cassian gastropods and locality data can be found in Bandel 1991, 1993a, 2007, 2009). The age of the Late Triassic Wortheniella coralliophila may be estimated to be about 220 Ma. The crystallographic texture of Wortheniella coralliophila was compared with data on living vetigastropods. Living vetigastropods have a uniform crystallographic texture (see Discussion) and therefore we present here data for only two species (Eastern Pacific Tegula funebralis (Adams, 1855) from the Oregon coast and Haliotis asinina Linnaeus, 1758, from the Queensland coast; lgt. J. Frýda), belonging to two phylogenetically distant clades of vetigastropods. The first species is a member of the family Turbinidae Rafinesque, 1815 (Turbinoidea Rafinesque, 1815), and the second of the family Haliotidae Rafinesque, 1815 (Haliotoidea Rafinesque, 1815; see Bouchet et al. 2005).
Gastropod shells selected for crystallographic texture analysis were gently broken to preserve information on the biological orientation of each shell fragment which may be valuable in future research. Several shell fragments of each species were studied under SEM (Fig. 1). Other fragments selected for crystallographic texture analysis were separately embedded in epoxy resin, and the biological orientation of each shell fragment was marked. Subsequently, each shell fragment was polished using a progressively finer polishing medium (down to $5 \mu \mathrm{m}$ grit $\mathrm{SiC}$ followed by several minutes with $3 \mu \mathrm{m}$ diamond, $1 \mu \mathrm{m}$ diamond, $0.25 \mu \mathrm{m}$ diamond, and $0.05 \mu \mathrm{m}$ colloidal silica). Samples were cleaned in an ultrasonic bath, dried at room temperature, and then carbon coated. Electron Backscatter Diffraction (EBSD) analysis was carried out in the Department of Geochemistry at the Czech Geological Survey using a Nordlys detector connected to a CamScan scanning electron microscope. The diffracted backscatter electrons producing a series of Kikuchi bands were collected by the Nordlys detector, and the crystallographic orientation of each measured biocrystal was evaluated by the EBSD acquisition software (HKL CHANNEL 5). 1000 to 5000 measurements were carried out on each nacre sample on a regular grid with a spacing of $15 \mu \mathrm{m}$. The maximum size of nacreous platelets is about $15 \mu \mathrm{m}$ (Fig. 1) and so the number of measurements roughly corresponds to the number of measured nacreous platelets in each shell sample. The orientation of each measured nacreous platelet was calculated and expressed as three Euler angles by the software package HKL CHANNEL 5. These values were subsequently recalculated as nine direct cosines for three basic crystallographic directions of aragonite (i.e., [100], [010], and [001]) and crystallographic direction [101] by the software package (Škeble). These crystallographic directions were plotted in a stereographic projection (Fig. 3) using the commercial software Spheristat (Pangaea Scientific). For the main crystallographic directions, three eigenvectors were calculated (their directions and magnitudes). Eigenvalues were then used for the calculation of two Woodcock's ratios ( $\mathrm{C}$ and $\mathrm{K}$ ) that, in turn, served for numerical evaluation of a textural type for each group of calculated vectors (Table 1). The $\mathrm{C}$ value is defined as $\ln (\mathrm{E} 3 / \mathrm{E} 1)$ and the $\mathrm{K}$ value as $\ln (\mathrm{E} 3 / \mathrm{E} 2) / \ln (\mathrm{E} 2 / \mathrm{E} 1)$, where $\mathrm{E} 1, \mathrm{E} 2$, and $\mathrm{E} 3$ are eigenvalues. The values of Woodcock's ratios were plotted on a modified Flinn diagram (Fig. 4).

\section{Results}

The SEM results show a well-preserved nacreous layer in all studied gastropod species including the Late Triassic Wortheniella coralliophila (Fig. 1). Results of texture analysis clearly indicate that the crystallographic direction [001] ( $c$ axis of aragonite) of all nacreous platelets in the 


\section{Wortheniella coralliophila}
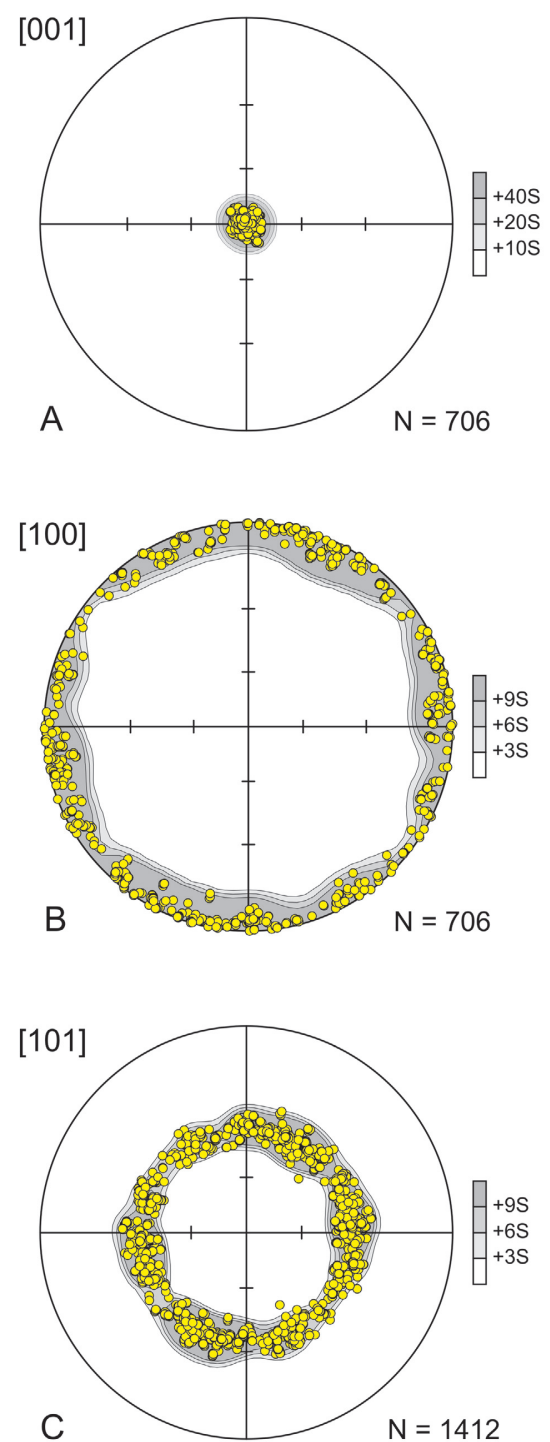

Haliotis asinina
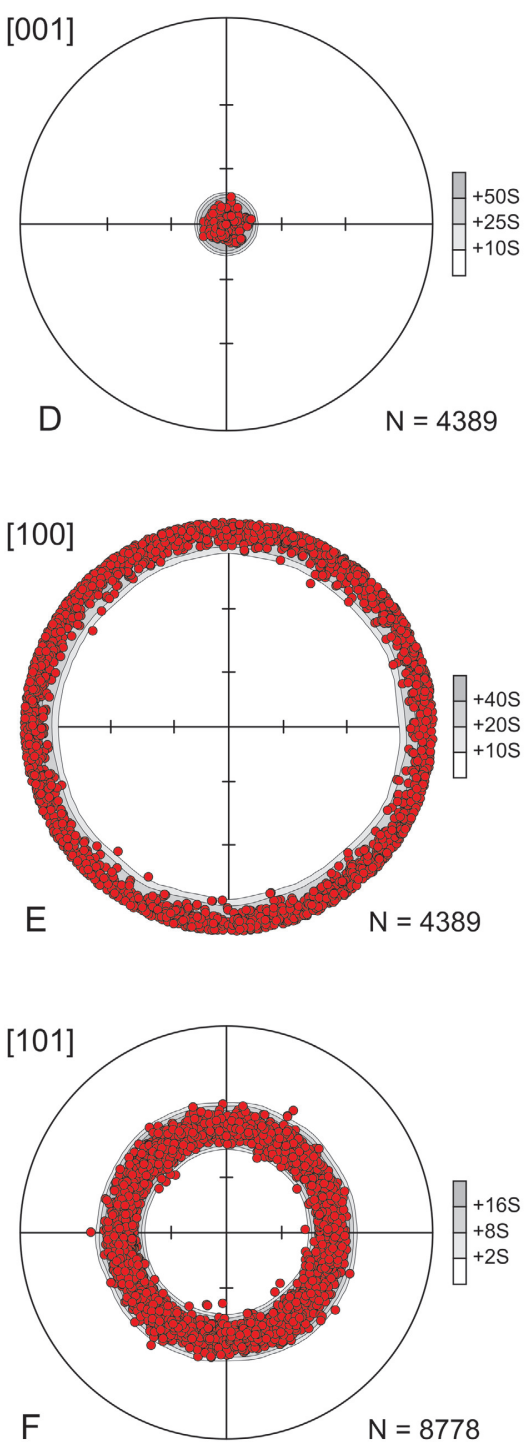

Tegula funebralis
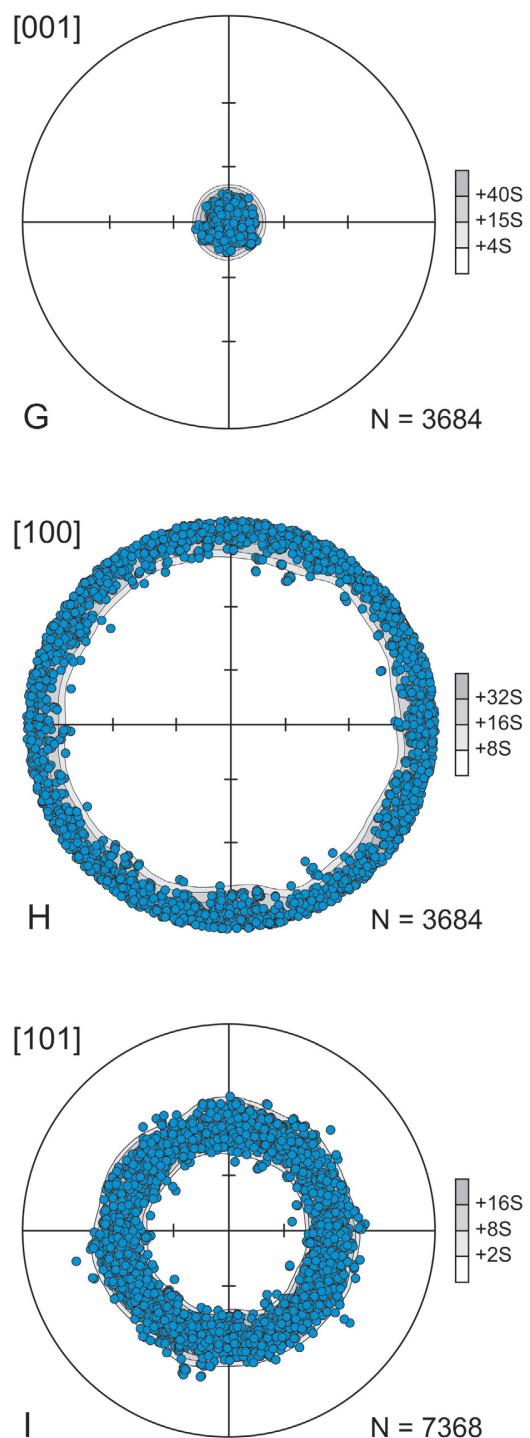

Figure 3. Results of crystallographic texture analysis of nacre in the Late Triassic Wortheniella coralliophila Kittl, 1891, and Recent Haliotis asinina Linné, 1758, and Tegula funebralis (Adams, 1855) figured in stereographic projection. • A-C - Wortheniella coralliophila. • D-F - Haliotis asinina. - G-I - Tegula funebralis. For all projections the direction perpendicular to the page is indentical with the direction perpendicular to the shell surface, direction from left to right is identical with growth direction of the shell (i.e., adapertural direction). A, D, G - crystallographic direction [001], B, E, H - crystallographic direction [100], C, F, I - crystallographic directions [101] and [101]; see text for detailed description.

Late Triassic Wortheniella coralliophila is perpendicular to the shell surface (Fig. 3A). Woodcock's C value for this crystallographic direction equals $5.506(5)$, and is much higher than the critical value $\mathrm{C}_{95}(=0.19)$ for a uniform distribution (significance level 0.05, Table 1). In other words, there is statistically significant evidence that the crystallographic $c$ axes of all nacreous platelets are not uniformly distributed. Woodcock's K value for the same crystallographic direction equals 8.8(1). Both Woodcock's ratios plotted on a modified Flinn diagram clearly show that the crystallographic axes $c$ for all nacreous platelets in Wortheniella coralliophila form a strongly developed cluster (Fig. 4). The same results were observed for the crystallographic $c$ axes of nacreous platelets in the living turbinid, Tegula funebralis, and the haliotid, Haliotis asinina (Table 1 and Fig. 3D, G).

On the other hand, the ordering of two perpendicular crystallographic directions [100] and [010] (i.e. the crystallographic $\boldsymbol{a}$ and $\boldsymbol{b}$ axes of aragonite) is different from that of [001]. The $\boldsymbol{a}$ and $\boldsymbol{b}$ directions have the same textural pattern 


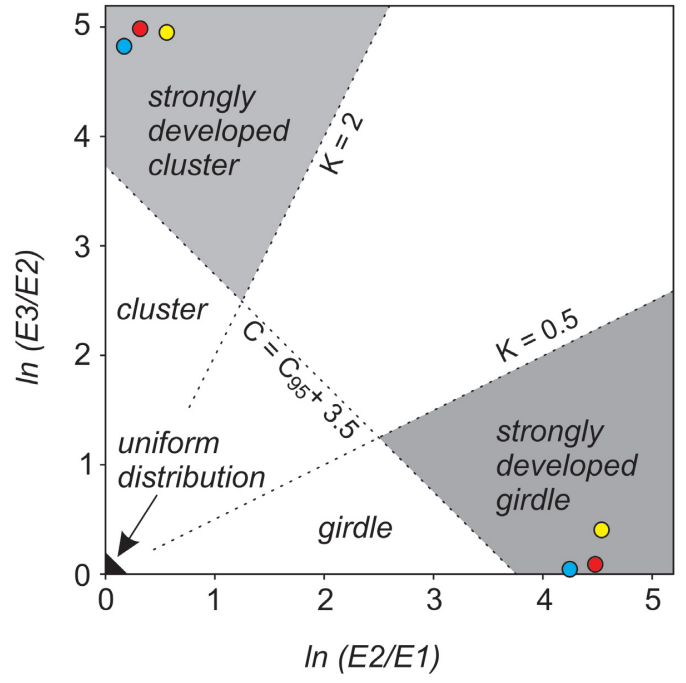

Figure 4. Calculated values of Woodcock's ratios plotted on a modified Flinn diagram. Wortheniella coralliophila (yellow), Haliotis asinina (red) and Tegula funebralis (blue); see text for details.

and so only the direction [100] (i.e., crystallographic $\boldsymbol{a}$ axis of aragonite) is discussed and plotted (Fig. 3B). Woodcock's C value for the crystallographic direction [100] in Wortheniella coralliophila equals 4.9(1), and is much higher than the critical value $\mathrm{C}_{95}(=0.19)$ for a random distribution (Table 1). However, Woodcock's K value for the same crystallographic direction equals only 0.089(2). Therefore, both values plotted on the modified Flinn diagram show that the crystallographic $\boldsymbol{a}$ axes of all nacreous platelets form a strongly developed girdle (Fig. 4). The same results were observed for the living turbinid, Tegula funebralis, and the haliotid, Haliotis asinina (Table 1 and Fig. 3E, H). In other words, the crystallographic texture of nacreous platelets in all studied gastropod species is strongly uniaxial. This means that one axis (c axis of aragonite) is in a strongly preferred orientation and is perpendicular to the shell surface, whereas the other two perpendicular axes ( $\boldsymbol{a}$ and $\boldsymbol{b}$ axes of aragonite) are randomly oriented. This textural type can be shown by a stereographic projection of crystallographic directions [001], [101] and [101] because all intersections of the latter vectors with a projection sphere appear in the same hemisphere (Fig. 3C), unlike intersections of [100] and [010] vectors. Note that the total number of plotted points for [101] and [101] vectors represents twice the number of measurements because these two crystallographic vectors could not be distinguished.

In total, the results of the textural analysis clearly demonstrate that the crystallographic texture of the nacreous shell layer in the Late Triassic Wortheniella coralliophila is identical with the crystallographic textures of nacre in the living turbinid, Tegula funebralis, and the haliotid, Haliotis asinina (see Figs 3 and 4).
Table 1. Calculated Woodcock's ratios ( $\mathrm{C}$ and $\mathrm{K}$ ) for crystallographic directions [100] and [001] (i.e., crystallographic $\boldsymbol{a}$ and $\boldsymbol{c}$ axes of aragonite), and the critical value $\mathrm{C}_{95}$ for a uniform distribution at significance level 0.05 for all studied species.

\begin{tabular}{llccccc}
\hline \multicolumn{7}{c}{ Woodcock's Ratio } \\
\hline & $\begin{array}{l}\text { Wortheniella } \\
\text { coralliophila }\end{array}$ & \multicolumn{2}{c}{$\begin{array}{c}\text { Haliotis } \\
\text { asinina }\end{array}$} & \multicolumn{2}{c}{$\begin{array}{c}\text { Tegula } \\
\text { funebralis }\end{array}$} \\
\hline Direction & {$[100]$} & {$[001]$} & {$[100]$} & {$[001]$} & {$[100]$} & {$[001]$} \\
$\mathrm{C}_{95}$ & 0.19 & 0.19 & 0.15 & 0.15 & 0.16 & 0.16 \\
$\mathrm{C}$ & 4.941 & 5.506 & 4.561 & 5.298 & 4.282 & 4.986 \\
$\mathrm{stD}$ & 0.106 & 0.005 & 0.015 & 0.002 & 0.014 & 0.001 \\
$\mathrm{~K}$ & 0.089 & 8.848 & 0.019 & 16.162 & 0.009 & 29.148 \\
$\mathrm{stD}$ & 0.002 & 0.134 & 0.000 & 0.125 & 0.000 & 0.205 \\
\hline
\end{tabular}

\section{Discussion}

Nacreous microstructure is secreted only in molluscs and occurs in four of the eight living molluscan classes, in Bivalvia, Tryblidia (Monoplacophora), Cephalopoda and Gastropoda. There are two microstructural patterns of nacre, sheet and columnar, which differ in the stacking mode of nacreous platelets. The nacreous platelets form sheets in Bivalvia and Tryblidia, and columns in Gastropoda (Fig. 1) and Cephalopoda. It has been shown that molluscan classes differ in the growth mechanisms of their nacre, causing its different microstructural and textural features (Wise 1970; Wada 1972; Mutvei 1978, 1980; Checa \& RodríguezNavarro 2001, 2005; Checa et al. 2008). Thus, each of the living molluscan classes has its own type of nacre (Chateigner et al. 2000).

The gastropod nacre is known only in one of five major living clades, in the majority of members of the Vetigastropoda. In vetigastropods, nacre is absent in some trochoideans (Phasianellidae, Halistylinae and Skeneidae) and in all species of Lepetodrilidae, Fissurellidae and Scissurellidae (Carter 1990, Ponder \& Lindberg 1997, Geiger et al. 2008). Hedegaard (1997) suggested that gastropod nacre was derived within the Vetigastropoda. On the other hand Frýda et al. (2004, and in press) showed that vetigastropod nacre is homologous with the nacre in some fossil cephalopods and pointed out that nacre is plesiomorphic in vetigastropods.

Recently published data on the internal relationships among major gastropod clades [e.g., Ponder and Lindberg 1997 - (Patellogastropoda (Neritimorpha (Vetigastropoda (Heterobranchia + Caenogastropoda) $))$ ) and McArthur \& Harasewych 2003 - (Patellogastropoda (Vetigastropoda (Neritimorpha (Heterobranchia + Caenogastropoda))))] appear to support a derived nature of gastropod nacre, because the Vetigastropoda are interpreted as not being the basal gastropod clade. Patellogastropoda lack nacre and 
are considered to be the sister taxon of the rest of the gastropods. The latter interpretation was based on analyses of morphological and anatomical data but is in conflict with the results of some molecular analyses (see references in Attipis et al. 2008). In addition, the interpretation of the patellogastropod fossil record seems to be also in conflict with their basal position (see Frýda et al. 2009 for discussion and references). The Patellogastropoda, as the first gastropod offshoot (Ponder \& Lindberg 1997), had to have split off from the rest of the gastropods (i.e. orthogastropods) before the Early Ordovician (Frýda \& Rohr 2004, Frýda et al. 2008a). The oldest fossil record for patellogastropods is, however, of a Late Triassic age (Hedegaard et al. 1997). Thus, there is no certain fossil record for the first half of the presumed patellogastropod evolution as an independent gastropod clade (i.e., missing data for about $250 \mathrm{Ma}$ ). Regardless as to whether gastropod nacre represents a plesiomorphic or derived character, it had to be lost independently in several vetigastropod lineages if the most recent model of vetigastropod phylogeny (Geiger et al. 2008, fig. 12.7) is to be accepted.

A direct study of the evolution of gastropod nacre is difficult because the oldest known nacreous gastropods come from the Carboniferous (e.g., Bandel et al. 2002) and there is only a low number of Late Paleozoic gastropods with a well-documented nacreous layer. Classification of the Paleozoic archaeogastropods at the family rank is still very unstable (compare Knight et al. 1960, Wagner 1999, and Bouchet et al. 2005). Nevertheless, Geiger et al. (2008) mentioned Euomphaloidea as the only vetigastropod group lacking nacre in their list of "major vetigastropod groups" originating in the Paleozoic. Thus all living vetigastropods lacking nacre originated after the Paleozoic time. The phylogenetic position of the extinct Euomphaloidea is uncertain (Bandel \& Frýda 1998; Nützel 2002; Frýda et al. 2006, 2008a). There is no reason to place them, together with all other extinct Paleozoic archaeogastropod families, within the Vetigastropoda because the latter clade is diagnosed by anatomic features that cannot be examined in extinct groups. Paleozoic Euomphaloidea as well as Macluritoidea may represent basal or sister taxa to the Archaeogastropoda (also including Vetigastropoda) as shown by their protoconch morphology (Frýda \& Rohr 2006). The members of the first group lack nacre (Bandel \& Frýda 1998), but there are no shell microstructure data for macluritoidean gastropods.

On the other hand, nacre was documented in species of the superfamily Porcellioidea Koken, 1895 in Zittel (1895), including some extinct archaeogastropods (Kiel \& Frýda 2004). Bandel (1993b) was the first to recognize the connection between the Paleozoic Porcelliidae and Mesozoic Cirridae and united them in one group. The oldest porcellioidean gastropods come from Silurian strata (Frýda 1997) and they became extinct during the Cretaceous
(Bandel 1993b). Morphological disparity within the Paleozoic porcellioideans is high, uniting sinistrally coiled shells with an apertural slit (Bandel 1993b) or tremata (Frýda et al. 2008b) or lacking the slit (Frýda \& Blodgett 1998, 2004; Frýda \& Farrell 2005). Some porcellioideans have bilaterally symmetrical adult shells, which were developed secondarily from sinistrally coiled shell (Frýda \& Blodgett 1998). In addition, openly coiled juvenile teleoconchs were documented in two Carboniferous genera (Bandel \& Frýda 2004, Frýda 2004). The Porcellioidea have been separated from the rest of the archaeogastropods (and therefore from vetigastropods if this group already existed) since the Silurian. Thus indirectly suggesting that archaeogastropods already had nacre in the Silurian if we reject the hypothesis that nacre originated independently in two archaeogastropod groups. This interpretation would suggest that nacre was present in the oldest gastropod groups (at least since the Silurian) and may represent a plesiomorphic feature not only in vetigastropods but also in all gastropods.

The studied species, the Late Triassic Wortheniella coralliophila, belongs to genus Wortheniella Schwardt, 1992, which was recently united by Bandel (2009) with the genera Bandelium Schwardt, 1992 and Rinaldoella Bandel, 2009 and placed into the family Wortheniellidae Bandel, 2009, of the Eotomarioidea Wenz, 1938. The latter superfamily was separated from the rest of the archaeogastropods during the Ordovician (type genus Eotomaria Ulrich \& Scofield, 1897, is Ordovician). If this model is correct, then it suggests the presence of nacre in the Ordovician (otherwise gastropod nacre had to be developed independently at least twice - in the eotomarioidean clade and in the ancestral groups of living vetigastropods).

\section{Conclusions}

New data on the Late Triassic gastropod Wortheniella coralliophila provides the first evidence for extremely long-term stability of a textural pattern in gastropod nacre. Extraordinary long-term stability of the morphological features of gastropod nacre has already been observed (Batten 1972, Bandel 1991, Bandel et al. 2002). The latter authors showed that the nacre of fossil gastropods is composed of many small platelets arranged in columns, thus having the same microstructure as the nacre of living gastropods. However our study is the first to show that not only the external shape and arrangement of nacreous platelets in living and extinct gastropods is identical, but also their crystallographic texture. The crystallographic axes of individual aragonite platelets in the Late Triassic Wortheniella coralliophila that lived about 220 million years ago have an identical arrangement with those in living vetigastropods. If the phylogenetic position of the genus Wortheniella is correct (i.e. a member of the superfamily Eotomarioidea 
Wenz, 1938, which has been separated from the rest of the archaeogastropods since the Ordovician - see Bandel 2009 and Knight et al. 1960), then gastropod nacre may have remained unchanged even longer - from the Ordovician to Recent.

Extremely long-term stability of microstructural features and crystallographic texture of gastropod nacre also implies that the biological mechanisms driving nacre origin and development were extremely stable in time. Suzuki et al. (2009) recently discovered two novel proteins (Pif80 and Pif97) that control the crystal structure and texture of nacre in living pearl-forming oysters. Our results thus suggest that the same or similar proteins controlling the shape and orientation of individual nacreous platelets in gastropods have not changed since at least Late Triassic, thus for $220 \mathrm{Ma}$. The present study indirectly suggests that the molecular mechanisms driving the origin and development of gastropod nacre are extremely old and have remained unchanged for several hundred million years.

\section{Acknowledgements}

This work was supported by grants from the Grant Agency of the Czech Republic (205/08/0062), the Ministry of Agriculture of the Czech Republic (Mze 0002700604) and the Czech-American Cooperation Program (Kontakt ME08011). The authors thank Tomáš Frýda (Prague) for his help with formulation of the software package Škeble, and Arthur J. Boucot (Oregon) and Michal Mergl (Pilsen) for their helpful reviews.

\section{References}

ADAMS, A. 1855. Further contributions towards the natural history of the Trochidae; with the description of a new genus and of several new species, from the Cumingian collection. Proceedings of the Zoological Society of London 22, 37-41.

AdDAdi, L., Joester, D., Nudelman, F. \& Weiner, S. 2006. Mollusk shell formation: A source of new concepts for understanding biomineralization processes. Chemistry - A European Journal 12, 980-987. DOI 10.1002/chem.200500980.

AKTIPIS, S.W., GiRIBET, G., LINDBERG, D.R. \& PONDER, W.F. 2008. Gastropoda - an overview and analysis, 201-237. In PONDER, W. \& LindBerg, D.L. (eds) Phylogeny and evolution of the Mollusca. 488 pp. University of California Press, Berkeley \& Los Angeles, California.

BANDEL, K. 1979. The nacreous layer in the shells of the gastropod family Seguenziidae and its taxonomic significance. Biomineralisation 1, 49-61.

BANDEL, K. 1982. Morphologie und Bildung der frühontogenetischen Gehäuse bei conchiferen Mollusken. Fazies 7, 1-198.

BANDEL, K. 1991. Schlitzbandschnecken mit perlmutteriger Schale aus den triassischen St. Cassian-Schichten der Dolomiten. Annalen des Naturhistorischen Museums in Wien $92,1-53$.
BANDEL, K. 1993a. Trochomorpha aus der triassischen St. Cassian Formation (Gastropoda, Dolomiten). Annalen des Naturhistorischen Museums in Wien 95, 1-99.

BANDEL, K. 1993b. Evolutionary history of sinstral archaeogastropods with and without slit (Cirroidea, Vetigastropoda). Freiberger Forschungshefte, Paläontologie C450, 41-82.

BANDEL, K. 2007. Description and classification of Late Triassic Neritimorpha (Gastropoda, Mollusca) from St. Cassian Formation, Italian Alps. Bulletin of Geosciences 82(3), 215-274. DO1 10.3140/bull.geosci.2007.03.215

BANDEL, K. 2009. The slit bearing nacreous Archaeogastropoda of the Triassic tropical reefs in the St. Cassian Formation with evaluation of the taxonomic value of the selenizone. Berliner paläontologische Abhandlungen 10, 5-47.

BANDEL, K. \& FRÝDA, J. 1998. Position of Euomphalidae in the system of the Gastropoda. Senckenbergiana lethaea 78, 103-131. DOI 10.1007/BF03042762

BANDEL, K. \& FRÝDA, J. 2004. Sasakiela, a new Early Carboniferous porcelliid genus (Porcellioidea, Gastropoda) with an unusual shell ontogeny. Neues Jahrbuch für Geologie und Paläontologie, Monatshefte 3, 135-150.

BAndel, K. \& GeldmaCher, W. 1996. The structure of the shell of Patella crenata connected with suggestions to the classification and evolution of the Archaeogastropoda. Freiberger Forschungsheft C464, 1-71.

BANDEL, K., NÜTZEL, A. \& YANCEY, T.E. 2002. Larval shells and shell microstructures of exceptionally well-preserved Late Carboniferous gastropods from the Buckhorn Asphalt deposit (Oklahoma, USA). Senckenbergiana lethaea 82(2), 639-689.

BATTEN, R.L. 1972. The ultrastructure of five common Pennsylvanian pleurotomarian gastropod species of Eastern United States. American Museum Novitates 2501, 1-34.

Bertoldi, K., Bigoni, D. \& DRUGan, W.J. 2008. Nacre: An orthotropic and bimodular elastic material. Composites Science and Technology 68, 1363-1375.

DOI 10.1016/j.compscitech.2007.11.016

BøGGILD, O.B. 1930. The shell structure of the mollusks. Det Kongelige Danske Videnskabernes Selskabs Skrifter, Naturvidenskabelige og Mathematiske Afdeling 9(II.2), 231-325.

BOUCHET, P., ROCROI, J.P., FRÝDA, J., HAUSDORF, B., PONDER, W., VALDES, A. \& WARÉN, A. 2005. Classification and nomenclator of gastropod families. Malacologia 47(1-2), 1-368.

CARTER, J.G. (ed.) 1990. Skeletal Biomineralisation: Patterns, Processes and evolutionary trends. Vol. II. Atlas and Index. 832 pp. Van Nostrand Reinhold, New York.

Chateigner, D., HedegaARD, C. \& WenK, H.-R. 2000. Mollusc shell microstructures and crystallographic textures. Journal of Structural Geology 22, 1723-1735. DOI 10.1016/S0191-8141(00)00088-2

CHECA, A.G., OKAMOTO, T. \& RAMíREZ, J. 2006. Organization pattern of nacre in Pteriidae (Bivalvia: Mollusca) explained by crystal competition. Proceedings of the Royal Society B 273, 1329-1337. DOI 10.1098/rspb.2005.3460

CHECA, A.G. \& Rodrigues-NAVARRO, A.B. 2001. Geometrical and crystallographic constraints determine the self-organization of shell microstructures in Unionidae (Bivalvia: Mollusca). Proceedings of the Royal Society of London, Series $B$ 268, 771-778. DOI 10.1098/rspb.2000.1415 
CHECA, A.G. \& Rodrigues-NAVARRO, A.B. 2005. Self-organisation of nacre in the shells of Pterioida (Bivalvia: Mollusca). Biomaterials 26, 1071-1079.

DOI 10.1016/j.biomaterials.2004.04.007

CHECA, A.G., RAmíreZ-Rico, J., GONZÁleZ-SEGURA, A. \& SÁNCHEZ-NAVAS, A. 2008. Nacre and false nacre (foliated aragonite) in extant monoplacophorans (= Tryblidiida: Mollusca). Naturwissenschaften 96(1), 111-122. DOI 10.1007/s00114-008-0461-1

FALINI, G., SHIRA ALBECK, S., WEINER, S. \& ADDADI, L. 1996. Control of aragonite or calcite polymorphism by mollusk shell macromolecules. Science 271(5245), 67-69.

DOI $10.1126 /$ science.271.5245.67

FRÝDA, J. 1997. Oldest representatives of the superfamily Cirroidea (Vetigastropoda) with notes on their early phylogeny. Journal of Paleontology 71(5), 839-847.

FRÝDA, J. 2004. Two new gastropod genera (Porcellioidea, Archaeogastropoda) from the Lower Carboniferous of Belgium. Journal of the Czech Geological Society 49(1-2), 57-61.

FRÝDA, J. \& BLODGETT, R.B. 1998. Two new cirroidean genera (Vetigastropoda, Archaeogastropoda) from the Emsian (late Early Devonian) of Alaska with notes on the early phylogeny of Cirroidea. Journal of Paleontology 72(2), 265-273.

FRÝDA, J. \& BLODGETT, R.B. 2004. New Emsian (late Early Devonian) gastropods from Limestone Mountain, Medfra B-4 quadrangle, west-central Alaska (Farewell terrane), and their paleobiogeographic affinities and evolutionary significance. Journal of Paleontology 78(1), 111-132.

DOI 10.1666/0022-3360(2004)078<0111:NELEDG>2.0.CO;2

FRÝDA, J., BLODGETT, R.B., LENZ, A.C. \& MANDA, Š. 2008b. New Porcellioidean gastropods from Early Devonian of Royal Creek area, Yukon Territory, Canada, with notes on their early phylogeny. Journal of Paleontology 82(3), 595-603.

DOI 10.1666/07-024.1

FRÝDA, J. \& FARRELL, J.R. 2005. Systematic position of two Early Devonian gastropods with sinistrally heterostrophic shells from the Garra Limestone, Larras Lee, New South Wales. Alcheringa 29, 229-240.

DOI $10.1080 / 03115510508619303$

FrÝDA, J., HEIDELBERGER, D. \& BlOdGETT, R.B. 2006. Odontomariinae, a new Middle Paleozoic subfamily of slit-bearing euomphaloidean gastropods (Euomphalomorpha, Gastropoda). Neues Jahrbuch für Geologie und Paläontologie, Monatshefte 4, 225-248.

FRÝDA, J., NÜTZEL, A. \& WAGNER, P.J. 2008a. Paleozoic gastropods, 237-268. In PONDER, W. \& LINDBERG, D.L. (eds) Phylogeny and evolution of the Mollusca. 488 pp. University of California Press, Berkeley \& Los Angeles, California.

FrÝdA, J., RACheboeUf, P.R., FrÝdOVÁ, B., FERrovÁ, L., MERGL, M. \& BERKYOVÁ, S. 2009. Platyceratid gastropods stem group of patellogastropods, neritimorphs or something else? Bulletin of Geosciences 84(1), 107-120.

DOI 10.3140/bull.geosci.1125

FrÝdA, J., RiEDER, M., KLEMENTOVÁ, M., WeItSChAT, W. \& BANDEL, K. 2004. Discovery of gastropod-type nacre in fossil cephalopods: a tale of two crystallographic textures, 43. In WELLS, F.E. (ed.) Abstracts, World Congress of Malacology, Perth 2004, Western Australia.

FRÝDA, J. \& ROHR, D.M. 2004. Gastropoda, 184-195. In
Webby, B.D., Paris, F., Droser, M.L. \& Percival, I.G. (eds) The Great Ordovician Biodiversification Event. 408 pp. Columbia University Press, New York.

FRÝDA, J. \& ROHR, D.M. 2006. Shell heterostrophy in Early Ordovician Macluritella Kirk, 1927, and its implications for phylogeny and classification of Macluritoidea (Gastropoda). Journal of Paleontology 80(2), 264-271.

DO] 10.1666/0022-3360(2006)080[0264:SHIEOM]2.0.CO;2

FUCHIGAMI, T. \& SASAKI, T. 2005. The shell structure of the Recent Patellogastropoda (Mollusca: Gastropoda). Palaeontological Research 9, 143-168. DOI 10.2517/prpsj.9.143

GEIGER, D.L., NÜTZEL, A. \& SASAKI, T. 2008. Vetigastropoda, 297-330. In PONDER, W. \& LindBerg, D.L. (eds) Phylogeny and evolution of the Mollusca. 488 pp. University of California Press, Berkeley \& Los Angeles, California.

HEDEGAARD, C. 1997. Shell structures of the Recent Vetigastropoda. Journal of Molluscan Studies 63, 369-377. DOI $10.1093 /$ mollus/63.3.369

HEDEGAARD, C. \& WENK, H.-R. 1998. Microstructure and texture patterns of mollusc shells. Journal of Molluscan Studies 64, 133-136. DOI 10.1093/mollus/64.1.133

HedegaArd, C., Lindberg, D.R. \& BAndel, K. 1997. Shell microstructure of a Triassic patellogastropod limpet. Lethaia 30, 331-335.

KIEL, S. \& FRÝDA, J. 2004. Shell structure of Late Cretaceous Sensuitrochus ferreri (Cirridae, Gastropoda). Journal of Paleontology 78(4), 795-797.

DOI 10.1666/0022-3360(2004)078<0795:NILCSF >2.0.CO;2

KITTL, E. 1891. Die Gastropoden der Schichten von St. Cassian der südalpinen Trias.Teil I. Annalen des kaiserlichköniglichen naturhistorischen Hofmuseums 6, 166-262.

KNight, J.B., Cox, L.R., BATten, R.L. \& Yochelson, E.L. 1960. Systematic descriptions. In MoORE, R.C. (ed.) Treatise on invertebrate paleontology. Part I. Mollusca 1. University of Kansas Press, Lawrence, Kansas.

LAUBE, G.C. 1868. Die Fauna der Schichten von St. Cassian. Kaiserliche Akademie der Wissenschaften, Denkschrift 28, 29-94.

LINNAEUS, C. 1758. Systema naturae per regna tria naturae: secundum classes, ordines, genera, species, cum characteribus, differentiis, synonymis, locis. 824 pp. Impensis Direct. Laurentii Salvii, Holmiae.

MCARTHUR, A.G. \& HARASEWYCH, M.G. 2003. Molecular systematics of the major lineages of the Gastropoda, 140-160. In LYDEARD, C. \& LINDBERG, D.R. (eds) Molecular Systematics and Phylogeography of Mollusks. 312 pp. Smithsonian Books, Washington.

MACCLINTOCK, C. 1968. Shell structure of patelloid and bellerophontoid gastropods (Mollusca). Peabody Museum of Natural History Bulletin 22, 1-140.

MARIN, F. \& LUQUet, G. 2004. Molluscan shell proteins. Comptes Rendus Palevol 3, 469-492.

DOI 10.1016/j.crpv.2004.07.009

Marin, F., Luquet, G., Marie, B. \& Medakovic, D. 2008. Molluscan shell proteins: primary structure, origin, and evolution. Current Topics in Developmental Biology 80, 210-277.

MUTVEI, H. 1978. Ultrastructural characteristics of the nacre in some gastropods. Zoologica Scripta 7, 287-296.

DO1 10.1111/j.1463-6409.1978.tb00612.x 
MutVeI, H. 1980. The nacreous layer in molluscan shells, 49-56. In OMORI, M. \& WATABE, N. (eds) The mechanisms of biomineralisation in animals and plants. Tokai University Press, Tokyo.

NÜTZEL, A. 2002. An evaluation of the recently proposed Palaeozoic gastropod subclass Euomphalomorpha. Palaeontology 45, 259-266. DOI 10.1111/1475-4983.00236

PONDER, W.F. \& LINDBERG, D.R. 1997. Towards a phylogeny of gastropod molluscs: an analysis using morphological characters. Zoological Journal of the Linnean Society 119, 83-265. DOI 10.1111/j.1096-3642.1997.tb00137.x

RAFINESQUE, C.S. 1815. Analyse de la nature ou tableau de l'univers et des corps organisés. 224 pp. Jean Barravecchia, Palerme.

SASAKI, T. 1998. Comparative anatomy and phylogeny of the Recent Archaeogastropoda. The University Museum. The University of Tokyo Bulletin 38, 1-223.

SASAKI, T. 2001. Macro- and microstructure of shell and operculum in two Recent gastropods, Nerita (Theliostyla) albicilla and Cinnalepeta pulchella (Neritopsina: Neritoidea). Paleontological Research 5(1), 21-31.

SCHWARDT, A. 1992. Revision der Wortheniella Gruppe (Archaeogastropoda) der Cassianer Schichten (Trias, Dolomiten). Annalen des Naturhistorischen Museums in Wien 94, 23-57.
Suzuki, M., Saruwatari, K., Kogure, T., Yamamoto, Y., Nishimura, T., KATO, T. \& NAgASAWA, H. 2009. An Acidic Matrix Protein, Pif, Is a Key Macromolecule for Nacre Formation. Science 325(5946), 1388-1390. DOI $10.1126 /$ science. 1173793

ULRICH, E.O. \& SCOFIELD, W.H. 1897. The Lower Silurian Gastropoda of Minnesota, 813-1081. In The Geology of Minnesota, Volume 3, Part 2, Paleontology. Harrison and Smith, Minneapolis.

WADA, K. 1972. Nucleation and growth of aragonite crystals in the nacre of some bivalve molluscs. Biomineralization 1972(4), 141-59.

WAGNER, P.J. 1999. Phylogenetics of the earliest anisostrophically coiled gastropods. Smithsonian Contributions to Paleobiology 88, 1-132.

WENZ, W. 1938-1944. Gastropoda, 1-1639. In SCHINDEWOLF, O.H. (ed.) Band 6, Teil 1-7, Handbuch der Paläozoologie. Borntraeger, Berlin.

WISE, S.W. 1970. Microarchitecture and mode of formation of nacre (mother of pearl) in pelecypods, gastropods and cephalopods. Eclogae Geologicae Helvetiae 63, 775-97.

ZITTEL, K.A. VON 1895. Grundzüge der Paläontologie (Paläozoologie), Abteilung I, Invertebrata. 971 pp. Oldenburg, München \& Leipzig. 